\title{
PENGEMBANGAN DESA BUAHAN SEBAGAI SENTRA AGROWISATA ORGANIC FARMING DI KECAMATAN KINTAMANI, KABUPATEN BANGLI
}

\author{
N.L. Kartini ${ }^{1}$, dan N.G.K. Roni ${ }^{2}$
}

\begin{abstract}
ABSTRAK
Pengembangan desa mitra bertujuan pelestarian danau batur dan meningkatkan pendapatan petani melalui pengembangan pertanian organik terpadu khususnya pertanian sayuran menuju desa sentra agrowisata organic farming, optimalisasi pengolahan limbah ternak menjadi pupuk organik dan biogas,mendorong kewirausahaan, produk unggulan dan pengembangan aktivitas pertanian menjadi paket wisata di Desa Buahan. Metode pemberdayaan masyarakat tiga (3) mitra melalui Program Pendampingan Desa Mitra adalah : (1) Partisifatory Rural Approach (2) Technology transfer, (3) Entrepreneurship capacity building. Hasil diperoleh menunjukkan bahwa kegiatan Program Pendampingan Desa Mitra di Desa Buahan, kecamatan Kintamani , Kabupaten Bangli dapat berlangsung dengan baik, adanya partisipasi aktif masyarakat melalui tiga mitra dan adopsi teknologi tinggi. Kemampuan adopsi teknologi dan inisiatif aplikasi teknologi ketiga mitra secara mandiri baru mencapai rata rata $60 \%$. Berdasarkan hasil panen bawang merah di luar musim memberikan hasil yang berbeda dimana pemberian kascing dan bioslurry $50,5 \mathrm{~g}$, biosllury $45,7 \mathrm{~g}$ dan kotoran sapi 41,6 g perumpun. Tumpangsari bawang merah cabai besar sesuai musim tanam, hasil bawang merah berbeda yaitu perlakuan kascing dan bioslury $56,8 \mathrm{~g}$, bioslury $50,4 \mathrm{~g}$ dan pupuk kandang sapi $42,8 \mathrm{~g}$ perumpun.
\end{abstract}

Kata kunci : pertanian organik, biogas, bioslurry, kascing, agrowisata.

\begin{abstract}
The development of partner villages is aimed at preserving Lake Batur and increasing farmers' income through the development of integrated organic agriculture, especially vegetable farming, towards organic farming agro tourism centers, optimizing the processing of livestock waste into organic fertilizer and biogas, encouraging entrepreneurship, superior products and developing agricultural activities into tourism packages in the village. Is not. The three (3) community empowerment methods through the Partner Village Assistance Program are: (1) Partisifatory Rural Approach (2) Technology transfer, (3) Entrepreneurship capacity building. The results obtained indicate that the activities of the Mitra Desa Assistance Program in Buahan Village, Kintamani sub-district, Bangli Regency can run well, there is active community participation through three partners and adoption of high technology. The ability of technology adoption and technology application initiatives of the three partners independently has only reached an average of $60 \%$. Based on the yield of onion in the off-season gives different results where the provision of vermicompost and bioslurry $50.5 \mathrm{~g}$, biosllury $45.7 \mathrm{~g}$ and cow dung $41.6 \mathrm{~g}$ per clump. Intercropping large chili onions according to the growing season, the results of different shallots are $56.8 \mathrm{~g}$ of vermicompost and treatments, $50.4 \mathrm{~g}$ of bioslury and $42.8 \mathrm{~g}$ of cattle manure.
\end{abstract}

Keywords: organic agriculture, biogas, bioslurry, vermicompost, agro-tourism

\footnotetext{
${ }^{1}$ Fakultas Pertanian, Universitas Udayana, luhkartini@unud.ac.id

2 Program Studi Peternakan Fakultas Peternakan Universitas Udayana, ketutroni@unud.ac.id
} 


\section{PENDAHULUAN}

Desa Buahan seluas 1.423 ha, terletak di tepi danau Batur, ketinggian 1245 - $1548 \mathrm{~m}$ dpl. Bentuk wilayah dari berbukit dan bergunung, kemiringan lereng 25 - 40\%,merupakan tujuan wisata baik domestik maupun mancanegara. Penduduknya sebagai petani sayur-mayur,tetapi belum banyak mendapatkan manfaat dari kegiatan pariwisata. Persoalan di Desa Buahan adalah penggunaan pupuk dan pestisida sintetis tidak terkendali menyebabkan pencemaran lingkungan danau batur, limbah peternakan belum semua terkelola, dari pascapanen belum menghasilkan produk, dan belum terbentuknya pengelola paket agrowisata.

Strategi diambil pemerintah menjadikan kawasan sekitar danau batur kawasan organik. Pemberdayaan petani melalui pengembangan wawasan agribisnis dan agrowisata perlu dilakukan dengan tetap dalam bingkai tatanan budaya Bali dan sumberdaya lokal . Ragam wisata dapat dikembangkan dengan pengemasan aktivitas pertanian organik terpadu (ternak sapi,biogas,cacing tanah, ikan, tanaman organik ) dan pengemasan aktivitas panen yang dapat dinikmati langsung menjadi paket wisata. Desa Buahan disisi Danau Batur dijumpai bentuk wilayah datar hingga berombak,termasuk dalam kawasan pariwisata Kintamani yang sudah sangat dikenal dengan pesona alam bukit,gunung dan danau batur yang eksotik.Berdasarkan hal tersebut maka Lembaga Pengabdian kepada Masyarakat Universitas Udayana melakukan kegiatan Program Pengembangan Desa Mitra di Desa Buahan Kecamatan Kintamani, Kabupaten Bangli.

\section{METODE PELAKSANAAN}

\subsection{Metode}

Metode digunakan dalam pelaksanaan program pengembangan desa mitra adalah : (1) Partisifatory Rural Approach adalah pendekatan partisipasif melibatkan masyarakat untuk semua tahap kegiatan mulai dari perencanaan pelaksanaan hingga evaluasi. Masyarakat sasaran ditempatkan sebagai subyek sehingga masyarakat yang lebih banyak aktif, tim pelaksana hanya sebagai motivator, fasilitator dan pendamping dalam transfer iptek dan rekayasa sosial.(2)Technology transfer, yaitu dalam pesolusian masalah bertumpu kepada transfer inovasi teknologi tepat guna kepada masyarakat sasaran untuk meningkatkan kinerja dan produktivitas usaha masyarakat. Adapun jenis teknologi tepat guna yang akan aplikasikan diantaranya : (1) teknologi fermentasi; (2) budidaya sayuran sistem organik di luar musim dan pada musim tanam; (3) teknologi pengolahan limbah ternak ; (4) degister biogas; (5) Vacum prying dan vacum sealing; (3)Entrepreneurship capacity building yaitu membangun wawasan kewirausahaan masyarakat melalui pembentuk kelompok usaha bersama pengolahan hasil sayuran.

\subsection{Tahapan Kegiatan}

Pelaksanaan kegiatan pendampingan program PPDM mengatasi persoalan yang sedang dihadapi oleh ketiga mitra (Kelompok Tani Organik, Kelompok ternak dan Kelompok wanita tani) di Desa Buahan adalah sebagai berikut : (1) Sosialisasi dan koordinasi pelaksanaan kegiatan dengan aparat desa dan masyarakat sasaran; (2) Pengembangan potensi pariwisata desa dengan sistem pertanian organik (3) pembuatan demplot tanaman bawang merah diluar musim tanam (4).Pemeliharaan biogas, pemanfaatan biosllury untuk mol dan budidaya cacing tanah,(5) demoplot tumpang sari bawang merah dan cabai besar, (6) pembuatan saus tomat dan bawang goreng dan pengemasan. 


\section{HASIL DAN PEMBAHASAN}

Kegiatan Program pendampingan ketiga kelompok mitra (Kelompok Tani Organik, Kelompok Ternak, dan Kelompok Wanita Tani) dilaksanakan di Desa Buahan Kecamatan Kintamani Kabupaten Bangli beranggotakan masing masing 20 orang, 15 orang dan 15 orang, selama 8 bulan (Maret - Oktober 2019). Kegiatannya adalah (1) desiminasi teknologi dilaksanakan melalui sosialisasi dan koordinasi pelaksanaan kegiatan dengan aparat desa dan ketiga kelompok mitra sasaran yang hadir 65 orang ; (2) Pengembangan potensi pariwisata desa dengan sistem pertanian organik (3) pembuatan demplot tanaman bawang merah diluar musim tanam (4).Pemeliharaan biogas, pemanfaatan biosllury untuk mol dan budidaya cacing tanah,(5) demoplot tumpang sari bawang merah dan cabai besar, (6) pembuatan saus tomat dan bawang goreng dan pengemasan

Kegiatan sosialisasi dan persiapan materi, kegiatan penyuluhan dan pelatihan dipusatkan di balai desa Buahan dan ditempat percontohan dengan ketiga mitra dan kegiatan pendampingan melalui pemeliharaan degester instalasi biogas ,pembuatan pupuk organik kascing, dan pembuatan biopestisida,penanaman bawang merah diluar musim dan penanaman bawang merah tumpang sari cabai besar di musim tanam. Ketiga mitra selama 4 bulan dilakukan kegiatan . Evaluasi kegiatan dilakukan pada setiap sub kegiatan melalui : (1) Evaluasi tingkat tiga mitra; (2) Evaluasi penguasaan teknologi; (3) Evaluasi terhadap kualitas produk yang dihasilkan.

Tabel 1.Partisipasi anggota kelompok ketiga mitra dan aparat desa

\begin{tabular}{|c|c|c|c|c|c|c|}
\hline \multirow[t]{2}{*}{ No. } & \multirow[t]{2}{*}{ Kegiatan } & \multicolumn{4}{|c|}{ Mitra } & \multirow[b]{2}{*}{$\%$} \\
\hline & & I & II & III & IV & \\
\hline A & $\begin{array}{l}\text { Kegiatan sosialisasi program kegiatan } \\
\text { PPDM }\end{array}$ & & & & & \\
\hline 1. & Absensi /kehadiran & 20 & 15 & 15 & 10 & 100 \\
\hline 2. & Mengungkapkan masalah & 11 & 9 & 5 & 5 & 30 \\
\hline 3. & Ikut Mencoba & 5 & 5 & 2 & 1 & \\
\hline $\mathrm{B}$ & Kegiatan & & & & & \\
\hline 1. & $\begin{array}{l}\text { Pengembangan potensi pariwisata } \\
\text { desa dengan sistem pertanian organik } \\
\text { (Absen/kehadiran) }\end{array}$ & 20 & 15 & 15 & 3 & 81 \\
\hline 2. & $\begin{array}{l}\text { pembuatan demplot tanaman bawang } \\
\text { merah diluar musim tanam } \\
\text { (Absen/kehadiran) }\end{array}$ & 20 & 15 & 15 & 4 & 83 \\
\hline 3. & $\begin{array}{l}\text { Pemeliharaan degister, pembuatan } \\
\text { kascing dan biopestisida dengan } \\
\text { memanfaatkan bioslurry } \\
\text { (Absen/kehadiran) }\end{array}$ & 15 & 10 & 3 & 5 & 51 \\
\hline 4. & $\begin{array}{l}\text { Pembuatan percontohan penggunaan } \\
\text { bioslurry,kascing dan pupuk kandang } \\
\text { untuk pemupukan bawang merah } \\
\text { tumpang sari cabai besar (absensi } \\
\text { /kehadiran) }\end{array}$ & 16 & 11 & 5 & 5 & 57 \\
\hline 5. & $\begin{array}{lrr}\begin{array}{l}\text { Pelatihan } \\
\text { goreng }\end{array} \text { dan } & \text { saos bawang } \\
\text { ((Absensi/kehadiran) } & \text { mengemas }\end{array}$ & 5 & 5 & 15 & 5 & 46 \\
\hline & & & & & & \\
\hline
\end{tabular}

Keterangan I= Kelompok tani organik Buahan, II.= Kelompok ternak buahan, III= Kelompok wanita Tani dan IV Aparat desa dan tokoh masyarakat

Berdasarkan Tabel 1 rata-rata partisipasi aktif anggota kelompok ketiga mitra dan aparat desa pada seluruh rangkaian kegiatan dari sisi kehadiran persentasenya tergolong tinggi.

Bioslurry hasil dari proses biogas digunakan langsung untuk pada tanaman bawang merah dengan tiga perlakuan ada petak diberikan pupuk kandang, ada petak yang diberikan bioslurry dan ada 
petak diberi pupuk kascing. Percobaan ini dilakukan di luar musim tidak menggunakan pestisida . Berdasarkan hasil panen memberikan hasilnya pemberian bioslurry 45,5 g per rumpun, pupuk kandang sapi beratnya 40,5 g/perumpun dan pemberian pupuk kascing 50,4 g perumpun . Tanaman bawang dengan perlakuan biosluury dan pupuk kascing ternyata tidak terserang hama dan penyakit berbeda dengan tanaman yang menggunakan pupuk kandang terjadi serangan hama dan penyakit. Keuntungan yang lain dari instalasi biogas mendapatkan gas metan dapat energi untuk memasak, merebus makan babi, masak saus dan bawang goreng. Percobaan juga dilakukan pada musim tanam dimana bawang merah tumpang sari dengan cabai (setelah bawang berumur 3 minggu baru ditanam cabai) dan tidak menggunakan pestisida. Berdasarkan hasil panen memberikan hasilnya pemberian bioslurry 49,5 g per rumpun, pupuk kandang sapi beratnya 40,8 g/perumpun dan pemberian pupuk kascing 58,4 g perumpun . Serangan hama dan penyakit hanya terjadi perlakuan yang menggunakan pupuk kandang.

Proses pertanian sistem pertanian organik, mulai dari pengolahan limbah pertanian/kotoran ternak menjadi pupuk beserta instalasinya, pembuatan biopestisida, teknik budidaya serta pengolahan produk pertanian menjadi olahan yang dapat dinikmati selanjutnya dikemas menjadi paket wisata. Biocyrcle farming akan menjadi atraksi wisata utama di Desa Buahan, atraksi lain berupa berkeliling danau membersihkan enceng gondok, serta menikmati hasil olahan ikan danau dan produk pertanian organik. Desa wisata agar mampu bersaing dan menarik bagi wisatawan harus memiliki daya tarik spesifik yang bersifat unik berbeda dari desa-desa wisata lainnya (Sardiana and Purnawan, 2016). Paket agrowisata tersebut selanjutnya harus dikelola oleh masyarakat lokal sehingga mampu memberikan kontribusi yang signifikan bagi kesejahteraan masyarakat desa (Sardiana dan Purnawan, 2015; Purnawan dan Sardiana, 2018). Dengan demikian, pendampingan mengenai peningkatan kapasitas masyarakat petani dalam mengelola wisata agro perlu dilakukan pada tahap-tahap selanjutnya.

\section{KESIMPULAN DAN SARAN}

Pelaksanaan kegiatan Program Pendampingan Desa Mitra Desa Buahan Kecamatan kintamani Kabupaten Bangli tahun 2019, maka dapat disimpulkan :

1. Sosialisasi dan koordinasi dengan Kepala Desa dan Aparat Desa Buahan masyarakat sasaran tentang pelaksanaan program PPDM telah dilakukan.

2. Pengembangan potensi pariwisata desa dengan sistem pertanian organik terpadu mulai diminati oleh petani.

3. Pemeliharaan degister, pembuatan kascing dan biopestisida dengan memanfaatkan bioslurry terealisasi $100 \%$

4. Pembangunan degister instalasi biogas untuk mengolah kotoran sapi menjadi bioslurry dan energi (gas metan ) untuk masak dan dapat meniadakan penggunaan kayu bakar

5. Biosllury dan Kascing dapat meningkatkan hasil bawang baik ditanam diluar musim tanam dan juga saat musim tanam bawang merah dan tidak terdapat serangan hama dan penyakit sedangkan yang menggunkan pupuk kandang sapi terdapat serangan hama dan penyakit.

6. Partisipasi ketiga mitra aktif pada seluruh kegiatan program pendampingan cukup tinggi yaitu 70\% (Kelompok Tani Organik Buahan): 55\% (Kelompok Ternak Buahan) dan 70\% (kelompok Wanita Tani Buahan).

\section{UCAPAN TERIMA KASIH}

Ucapan terima kasih disampaikan kepada KEMENRISTEK DIKTI atas dana yang diberikan melalui program PPDM, Rektor Universitas Udayana, Ketua LPPM beserta staf dan staf lapangan sehingga pengabdian kepada masyarakat terlaksana dengan baik dan sesuai rencana. 


\section{DAFTAR PUSTAKA}

Anon, 2015. Monografi Desa Buahan, Kecamatan Kintamani, Kabupaten Bangli.

Purnawan, NLR., I.K Sardiana. 2017. Paket Wisata Edukasi Subak Upaya Menjaga Keberlanjutan Potensi Pertanian dan Pariwisata Berbasis Budaya di Bali. Jurnal Kawistara 7 (3), 275-284

Roni, NGK. 2015. Aplikasi biofermentasi kulit coklat dengan probiotik menjadi pakan berkualitas untuk meningkatkan produktivitas sapi kereman di desa Telaga, Busungbiu, Buleleng. Udayana Mengabdi. Volume 14 Nomor 2 tahun 2015

Roni, NGK. 2015. Performans dan indeks kelembaban suhu kelinci jantan (Lepus nigricollis) yang dipelihara dengan luas lantai kandang dan diberi ransum dengan imbangan energi dan protein berbeda . Majalah Ilmiah Peternakan, Volume 18 Nomor 1 tahun 2015

Sardiana, IK., NLR Purnawan., 2016. Indigenous community, ecotourism and sustainability: Experience from Tenganan Dauh Tukad traditional. Heritage, Culture and Society: Research agenda and best practices in the hospitality and tourism ind | vol: | issue : |2016-01-01 | Conference Proceedin

Sardiana, IK., NLR Purnawan. 2015. Community-based Ecotourism in Tenganan Dauh Tukad: An Indigenous Conservation Perspective. Jurnal Kajian Bali (Journal of Bali Studies) 5 (2), 347-368

Sardiana, IK., I M. Adnyana, IB.P.Manuaba, IGAMSA. 2014. Soil Organic Carbon, Labile Carbon and Organic Carbon Storage under Organic and Conventional Systems of Chinese Cabbage in Baturiti, Bali Indonesia. Journal of Biology, Agriculture and Healthcare 4 (12), 63-7

Sardiana, IK. 2017. Strategi Transisi dari Pertanian Konvensional ke Sistem Organik pada Pertanian Sayuran di Kecamatan Baturiti, Kabupaten Tabanan, Bali.

Sardiana, IK., D Susila, AA Supadma, M Saifulloh. 2017. Soil Fertility Evaluation and Land Management of Dryland Farming at Tegallalang Sub-District, Gianyar Regency, Bali, Indonesia. IOP Conference Series: Earth and Environmental Science 98 (1), 012043 